\title{
Language and Symbolic Arts: Religious Adornments, Arts and Meaning in the Catholic Church Liturgy
}

\author{
Josephine Marie A. Eke \\ Department of General Studies, Plateau State University, Bokkos, Nigeria \\ Email: srjoeany@yahoo.com
}

How to cite this paper: Eke, J. M. A. (2020). Language and Symbolic Arts: Religious Adornments, Arts and Meaning in the Catholic Church Liturgy. Open Journal of Modern Linguistics, 10, 390-403. https://doi.org/10.4236/ojml.2020.104023

Received: July 21, 2020

Accepted: August 25, 2020

Published: August 28, 2020

Copyright $\odot 2020$ by author(s) and Scientific Research Publishing Inc. This work is licensed under the Creative Commons Attribution International License (CC BY 4.0).

http://creativecommons.org/licenses/by/4.0/

\section{(c) (i) Open Access}

\begin{abstract}
Language is a means, a tool or method, of verbal or non-verbal communication between humans using some forms of signs, and symbols such as letters of the alphabets in written form to make words used in speech that convey meanings. The use of these words is done following the rules of grammar. Every culture/race or people have their own language and symbols and the way they communicate. Language enables one to express feelings, thoughts, ideas and shared experiences. Symbols have mystical quality that conveys a sense of the sacred and gives nourishment to the physical. Through working with symbols the inner energy is harnessed or put in use; one thinks deeper than the ordinary. Unless these symbols are understood they make no meaning and therefore have no effect on the individual. Therefore religious arts and symbols are creative images designed to aid and inspire the individual to reflect in the spiritual. The Catholic Church is one Religious Institution that uses a lot of symbols and art in religious worship or liturgy. The Liturgy is the religious way of life which is centered in the Mass or Eucharistic celebration. Its religious arts-places, objects, arts, (icons, pictures), and adornments are dressing or vestments, vessels, and decorations (flowers, vestments seasons and colours). This article tries to explain briefly what language means. It also attempts to expose to the reader the uses of some of the symbols, arts and adornment in the Catholic Church, noting their possible meaning and how they affect the life of the faithful for spiritual enhancement or growth.
\end{abstract}

\section{Keywords}

Language, Catholic Church Liturgy, Symbolic Arts, Adornments 


\section{Introduction}

\subsection{Language}

Language is a sole medium of communication between two persons, through which they can share their views, ideas, opinions and emotions with one another. It is aimed at making sense of complex and abstract thought without any confusion through clarity of expression. As a system of communication, different languages are used by people residing in different areas or belonging to a different community. Since communication is the process through which language is expressed in order to give the message, language therefore must be intelligible and productive. Language can be verbal communication (spoken or written) or non-verbal (use of symbols, sign language and body language). According to Goldstein (2008), language can be defined as a system of communication using sounds or symbols that enable us to express our feelings, thoughts, ideas, and experiences.

\subsection{The Catholic Church and Liturgy}

The Catholic Church also referred to as Roman Catholic Church, has its liturgical language which is however pragmatic. The liturgy is always within a particular kind of language whose unity seems assured, among other things. It is language specific to the ritual of the community. Zimmerman (1998: p. 52) stated that liturgy exploits the event of the Paschal Mystery, but at the same time enables innovation for the here and now celebrating community. This liturgical language is full of symbolic modes of expression, and keywords that relate to key experiences of a people, narrative or storytelling, and the modes of address that flow from these (Power, 1990: p. 70). Power added that symbolic language is rooted in bodily expression, that what people feel, express and experience in bodily modes constitute a primary perception and sense of reality. The Catholic liturgy as expressed in The Catechism of the Catholic Church, (CCC) (2008, art 1382: p. 307) - the Mass is at the same time, a sacrifice, a memorial and a re-enactment of the sacrifice of Christ on the cross, and the sacred banquet of communion with the Lord's body and blood. The Catholic liturgical language components or symbols include gestures, postures, movements (body language), places, objects, arts (icons, pictures), music (songs chants), adornment and decorative elements (flowers, vestments, seasons and colours), as well as spoken statements (homily, readings). From the vestibule (sacristy) where the Priest dresses to the conclusion of the Mass, a lot of actions and things are used and these have their meaning.

\subsection{Symbols and Arts}

Symbols and arts are images in action. In this write up symbolic arts, call to consciousness awakening, of the interior being, the spirit of the human person. In scripture you hear the prophet Samuel say "speak Lord your servant is listening" (1 Sam. 3: 10). Prophet Jeremiah goes to the Potter's house to watch him 
make the pot (Jer. 18: 1-6). It is imagery that speaks, so are symbols. Signs, symbols and Arts are able to communicate in a way that is out of the ordinary. They are inanimate (non-verbal) that awaken the conscience and give message/meaning in an extra ordinary manner. Langer (1980: p. 28) corroborated that symbols are recognized key to mental life “symbols and meaning make man's world far more than sensation".

The Catholic Church is rich with symbolic expressions: every aspect of Liturgy is loaded with signs and symbols. In Liturgy symbols are actions and signs whose meaning comes from the inspired word of God. "They carry many layers of meaning available to the unlearned and challenging to the theologian" (Bosch, 2001: Essay 5). They are pregnant images, living words, and hope-filled thrusts. "Art is a freely given superabundance of the human being's inner riches" (CCC, 2008, art 2501: p. 523). However, the emotional attitude or response to the nonverbal codes remains largely difficult to evaluate or appreciate except the individual expresses it. If there is no impact, there will not be any behavior modification or spiritual impact. "Christian symbols are not vague intellectual image to be grasped by the mind alone" (Byrne in Leaver (1998: p. 72)). Symbols in the Catholic Church are often permanent; one does not need to invent them weekly. When they are used well the community is enriched in their worship.

\subsection{Arts and Adornment}

Art in the Catholic Church would therefore include everything from drawings, paintings, vessels used, clothes, adornment, flowers, building of various edifices and crafts from various cultural backgrounds, of "fine" art, music, art enlightens the mind and heart as well as beautifies. It has other functions as well: it educates; that is teaches a lesson that can be stated in rational language. Therefore, a picture for example of the Divine Mercy of Jesus with a caption "Jesus I Trust in Thee" is didactic if the caption tells one what to think about and sets the mind in motion. Art illustrates and can illustrate a truth. When you go on pilgrimage to Holy sites like Rome, Jerusalem etcetera you are overwhelmed by a lot of great Christian art, illustrating Bible stories so that one can understand them and visualize them better. Art can also inspire. The beauty of form and content can lift hearts and minds to higher, more, pure and lofty things. The highest forms of art do this by touching our emotions. This is the essence of Art and symbols in the Catholic Church. Dwight (blog March 23, 2018) noted that Art is like worship. They are creative images to aid spiritual growth. Through the emotional encounter one is engaged with Truth at a deeper than discursive level. This experiential level with Truth incarnated is often in a way that is beyond analysis and explanation. It is at the deepest level of one's humanity, and it enlightens one or shades light to the darkness in the self. This brings about transformation or spiritual enhancement. Some of the Religious Art and Symbols in the Catholic Church that will be discussed are: places, objects, arts (icons, pictures), adornment, decorative elements (flowers, vestments, seasons and colours) with their 
meaning. Listed items that make up the various groups in the article will be looked at under their main headings.

\section{Art and Symbols: Places, Objects, Arts}

The New Jerusalem Bible (1990) which has been used for biblical references has many examples supporting various arts and symbols in the Church.

\subsection{Altar}

This is a place of sacrifice. The altar and all the instruments of the Eucharist stand as symbols of God's forgiveness and his continuing redemption and sanctification. The Lord God ordered Abraham to offer Isaac his only son to him. Abraham had the boy bound up and placed on the altar ready to kill him. He raised his hand up to stab Isaac to death but was halted by an Angel (Gen 22: 1-19). Abraham's sacrifice was a symbol of what the Lord will do in a future time when he offered up his only begotten Son, Our Lord Jesus on the Altar of Calvary. This Christ said, should be done in memory of him. So the priest continues to offer this sacrifice-Mass on behalf of mankind. Le Joly, (1995: p. 84) noted "the bread of Christ is better than the manna in the desert... but Jesus tells them to see this 'sign' in its true perspective, in its prophetical meaning: the Bread I shall give is my flesh for the life of the world (Jn. 6: 52). It is a spiritual not a material food. For a sacrifice to be carried out, there must be a place for it-an altar. Without an altar, there is no sacrifice. Christ continues to be the sacrifice in atonement for sins. He has asked us to offer this Eucharistic sacrifice as a memorial. Therefore, this is the reason for an altar. Abraham, Melchizedek, Abel, chose lamb for sacrifice (Gen 4: 1-7). Noah (best representative of each surviving animal and bird (Gen 8: 20-21) all had material wealth to offer to God as sacrifice. Jesus had none; he chose to give himself freely, a lamb without blemish. $\mathrm{He}$ was a priest, an unblemished victim, and a holocaust for the salvation of all. As cited in The Divine Office (2011: p. 292, Cat 3: 13-19), John Chrysostom talked about the Lamb without blemish as representative of the 'Lord's blood'". It has "saving act" the blood of sheep without reason he said naturally cannot save man endowed with reason. Therefore the blood of sheep smeared at the doorposts of the Israelites was not because it was blood but because it prefigured the Lord's blood.

\subsection{The Chalice, Paten and Ciborium}

The Chalice or cup is the vessel that contains the consecrated wine of the Eucharist. The Paten is the flat plate used to carry the Host. It symbolizes the dish used at the Last Supper. It symbolizes the Ark of the Covenant in the Old Testament. The Ciborium holds hosts for, and after, the Eucharist, thus the counterpart of the chalice. Since the saint had died "in Christ" the ciborium also symbolizes the tomb of the Holy Sepulcher from which Christ had resurrected, therefore, a symbol of hope for the faithful. As Old Testament analogies to the 
Eucharistic sacrifice and hierarchic priesthood which was developed in the third and fourth century, the ciborium also symbolized the Holy of Holies of the Old Testament Temple along with the chancel area in general. To show that the Holy of holies was a sacred area, curtains were hung between the columns of the ciborium and kept closed except for Mass; opened for Mass to symbolize the rending of the Temple's curtain and subsequent, unobstructed accessibility to God. This is why there is a Tabernacle and the Sacred species kept in the ciborium is reserved in it.

\subsection{Bells}

Bells also are used for worship. They have an important function. The ringing of the bell marks various points of the liturgy; at the elevation of the Host and Chalice, before Communion, by the Mass server as he accompanies the priest taking the Holy Communion. The ringing keeps the faithful alert to Divine presence. Bells fringed the priestly robe of Aaron in the Old Testament (Exodus 28: 33-34, 39: 25-26).

\subsection{The Thurible or Censer and Incense}

The thurible is the name of the incense "basket" on chains. A thurible is a metal censer suspended from chains, in which incense is burned during worship. It is used to incense people and items through the course of the Mass. Incense is an aromatic substance which gives out its perfume or scent when burnt. It symbolizes the prayers of the people ascending to God (Ps. 141: 2; Rev. 5: 8, 8: 3-4). In the Jewish tradition, incense was used as a sacrifice to God with serious guidelines concerning its use in the Holy place (Ex 30: 22-38, Leviticus 16: 12-13). In liturgy, it is burnt in a metal vessel called thurible or censer swung to distribute its fragrance. This practice includes censing the celebrant, the altar and the people. It is used in Eastern Orthodox, by Catholics and other churches. Incense is used to show reverence for the Eucharist. This also is to dispel evil and to fill the individual with Christ. Christ therefore spreads his fragrance everywhere dispelling evil. Christ is the sacrifice to God that yields an odor of sweetness (2 Cor. 2: 15). Christians are expected to spread this fragrance of Christ to others.

\subsection{Candles}

Candles are used always in the church during worship. In the Old Testament, light signifies God's presence and holiness (Ps 27: 1. Is. 9: 2. 2 Cor. 4: 4-6, 1 Tim 6: $16.1 \mathrm{Jn} .1: 15)$. In the New Testament the children of God are identified as children of light and bearers of light (Matt 5: 14-16. Jn. 12: 36, Eph. 5: 8, 1 Thess 5: 5). Light is also a primary source of Christ, the illuminator of God to man. "I am the light of the world" (Jn. 1:4). He as the light of the world is often symbolized by a candle. It is commonplace to keep candles on each side of the altar, to signify the two natures of Christ; divine and human. These two sources of light are united at the table of the Eucharist where the cup and bread are placed. Its 
utilitarian purpose is to provide illumination for the purpose of worship. However, Bosch (2001: Essay 5) stated "the symbolic meaning of light has been obvious to religious sensibilities since the beginning of human story; we can suppose evoking a sense of the sacred almost universally in human heart" In the Catholic Church, there is a "sanctuary lamp". This is kept as a sign of the presence of a "reserved host", that is Communion, set aside in a previous Eucharistic celebration, but unconsumed, and "reserved" in the tabernacle for the distribution at some later time or to be taken to the sick or other communicants who were not able to come for Mass due to ill health or imprisonments or are incapacitated.

\subsection{The Bible/Missal}

This is one of the most important "signs" of Christians worship. It represents and presents to the faithful the "Word" of God, which is the food for their souls. It is one of the main tools of Christian worship. The Bible is among the chieftools in your toolbox as a worship leader (Bosch, 2001: Essay 5).

\section{The Church Calendar of Seasons, and Colours of Vestments (Time: Yearly, Weekly and Daily Cycles)}

\subsection{The Catholic Church Liturgy}

The Catholic Church Liturgy specifies what to use at various occasions. The Ordor designates among other information, the colour of the vestments (garments) to be worn for a specific liturgy, on a certain day. These seasons and vestments have meanings as well. They render beauty to the celebrations and therefore they are artistic. The seasons begin with purple and end with green, and occasionally with white and red in between the seasons. As stipulated by the Church, different colors represent different liturgical seasons. Since around the sixth century, the primary liturgical colours have been green, white, purple, red and black. Our society is affected by things such as clothes. They offer signals relating to status and individuality. The way people behave and relate to their wears can suggest something about their emotion and appearance. In the Catholic Church, the vestments, altar clothes and colours give a lot of messages to the faithful and also suggest the mood of prayer.

\subsection{Seasons in the Catholic Church}

Dewis (2002: p. 18) in the Weekday Missal, is stated that it is important to select and arrange the forms and elements proposed by the Church, which taking into account individual and local circumstances, will best foster active and full participation and promote the spiritual welfare of the faithful. Therefore in celebrating the Liturgy, certain vessels as well as vestments are used according to the stated rubrics (code of conduct/rites/regulations for Liturgy).

1) Advent

Advent begins the Christian Liturgical year. It is the season for looking for- 
ward. Christians prepare for the remembrance of Christ's birth at Christmas and wait expectantly for Christ's second coming; as did John the Baptist. The faithful anticipates the joy of Christ's second coming and judgments. So they look forward in both happiness and penitential preparation. The season is marked with intense, yet devout and joyful expectation as the faithful recall the first humble coming of the Lord at Bethlehem.

Advent begins four Sundays before Christmas Day a specific colour of vestment is used.

Alva (2002: p. 138) notes:

Some churches use blue as the advent color-the color associated with the Virgin Mary. But the most common liturgical color for advent is purple or violet, the color of penitence but also the color of royalty, signaling the coming of the Kings of kings.

\section{2) Christmas}

During this season, Christians rejoice in Christ's birth. "To you is born this day in the city of David, a Saviour, who is the Messiah, the Lord" (Lk. 2: 10-11). This period extends to the Sunday of Epiphany. The colour used right up to the first Sunday of Epiphany is white meaning purity, innocence or holiness. Epiphany means in Greek "manifestation", and is celebrated on January 6 every year, commemorating the manifestation of Christ to the Gentiles. The Magi who visited the Christ child are seen as representing all the non-Jews to whom Christ came.

\section{3) Ordinary Time}

This period continues after the feast of Epiphany right up to Lent. Ordinary time can also be referred as the Epiphany season. The main colour is Green. Green signifies life. Christians have been brought to life and life has been given to them. They are reminded to pass on that life to others, to proclaim, to manifest Christ-the way, the truth and the life to others. Depending on the various events during the Ordinary time, other colours may be used according to the events.

\section{4) Lent}

Ash Wednesday beings the season of Lent. It is a time for preparation, fasting prayer and almsgiving. Jesus' preparation for his public ministry began with forty days of fasting and prayer in the wilderness. The forty days of Lent commemorate this period and Christ's choice of the way of the cross instead of all the good promises of Satan. The colour during this period is violet or purple which also symbolizes passion or penitence.

\section{5) Easter}

Easter is the oldest of Christian festivals, the feast of feasts, the most joyous of Christian observances. It is the time to commemorate the resurrection of Christ and the restoration of life to the world in which sin brought death. In many Christian traditions baptism, a symbol of the believer's identification with Christ in his death, burial and resurrection is carried out. Easter season includes five Sundays after Easter, leading to Ascension Thursday (Forty Days after Easter); 
this day is at times transferred to a Sunday. Christians are called to live out the love of God and neighbor as Christ did on the Cross. White is the colour used during this season. White symbolizes purity.

\section{6) Pentecost}

This season corresponds to the Jewish festival of Weeks or Pentecost in the same way the Christian Easter corresponds to the Jewish Passover. The Pentecost is fifty days after Easter. With it comes the end of Easter season, and the Catholic Ordinary time calendar continues till last week of November when the Christian calendar begins again with Advent. The celebration of Pentecost is done with the colour Red symbolizing power, strength, emotions etc. After the celebration of Pentecost, the Sunday following is the Trinity Sunday, after which the church calendar goes back to Ordinary time till first Sunday of advent. Again with Pentecost, Christians are expected to go out with power and without fear to proclaim the good news of salvation.

\subsection{Colours and Meanings}

Colour is filled with information and it is one of the most pervasive sources of communication. It associates heavily with our environment, grass, trees, sky, water, and earth. Colour "speaks" if one may say so and helps to set the mood for the celebrations. Various cultures have their interpretations of colours. Colour response is basically an individual reaction-that is subjective.

Krier (1988: p. 21) makes the following observations of colours:

Yellow: Sun, light, power, truth, insanity, cowardice, warmth.

Red: Power, strength, daring emotional, and active.

Blue: Good, heaven, soft, and passive.

Purple: Intelligence, knowledge, pride, passion, royalty.

The more intense the colour is, the more highly emotional the message. Conversely, the less intense the colour, the more restful it becomes.

Noonan Jr. (1996: p. 486) gives a traditional usage for vestment colours as well as their symbolism (p. 342) in the Catholic Church (Table 1).

Table 1. Traditional usage for vestment colours as well as their symbolism.

\begin{tabular}{|c|c|c|}
\hline Colour & Season & $\begin{array}{c}\text { Symbolism } \\
\text { (Positive associations) }\end{array}$ \\
\hline Green & Masses in Ordinary time & $\begin{array}{l}\text { Hope, everlasting life, } \\
\text { fidelity, growth, fertility }\end{array}$ \\
\hline White & $\begin{array}{l}\text { Christmas, Easter, Feasts and memorials of the Lord } \\
\text { other than His Passion. The conversion of Paul, Feasts } \\
\text { of Blessed Virgin Mary, Birth of John the Baptist, } \\
\text { Of Saints and Virgins, All Saints (Nov } 1^{\text {st }}{ }^{\star} \text { Funerals } \\
\text { (Optional) (* asterisk), The Chair of Peter }\end{array}$ & $\begin{array}{l}\text { Joy, exuberance, } \\
\text { celebration } \\
\text { resurrection, victory, } \\
\text { purity, innocence }\end{array}$ \\
\hline Gold and Silver & for Most Solemn Feasts & Same as white \\
\hline Red & $\begin{array}{c}\text { Pentecost, Good Friday, Palm Sunday (Passion Sunday), } \\
\text { Feast of Martyrs, Birthday feasts of the Apostles and } \\
\text { Evangelists and celebrations of Martyrs }\end{array}$ & $\begin{array}{l}\text { Holy spirit, suffering of } \\
\text { the lord, of the apostles } \\
\text { and for martyrdom }\end{array}$ \\
\hline
\end{tabular}




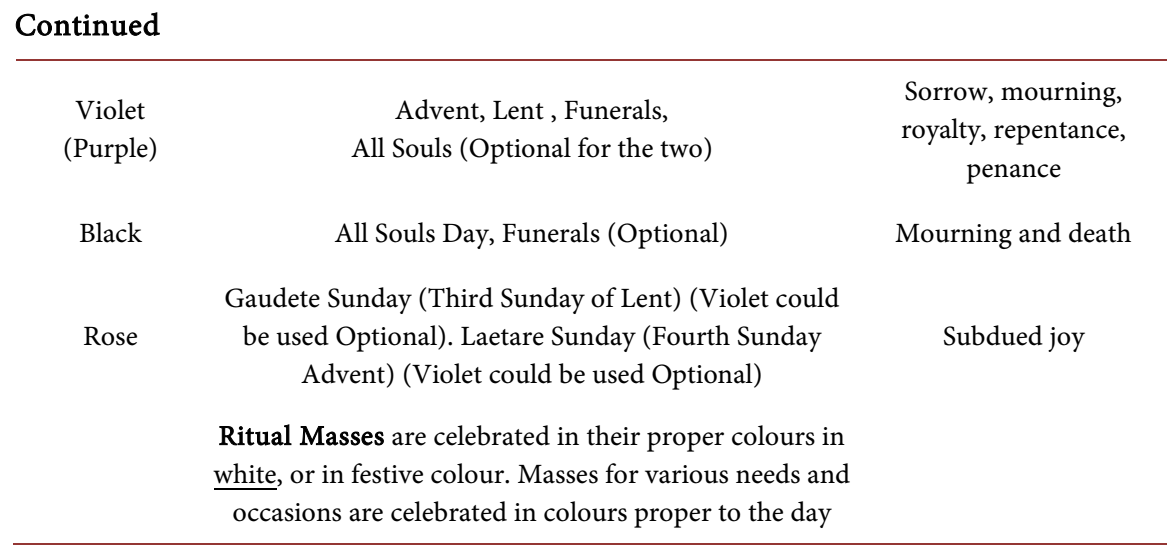

Black: This symbolizes mourning or grief (Isaiah 50: 3; Jer. 4: 28). It is associated with solemnity, negation, sickliness, and death. Black is inherently ominous since it represents the unknown, a feature it shares with death. When a nation is thrown into mourning black is often used.

Blue: This represents many things: heaven, infinity, spiritual love, truth, constancy and fidelity. The Virgin Mary is often depicted wearing a blue robe.

Brown/Gray: These are lifeless colours, colour of ashes commonly used in Religious houses (Monasteries and Convents). It signifies poverty, mortification, mourning and humility.

Gold and Yellow: This almost universally symbolizes the sun as well as divine illumination, purity, immortality, and wisdom. In Christian tradition, they are used primarily to represent purity, divinity and kingship. In Eastern orthodoxy, gold represents perfection and light of heaven.

Purple: is also an indication of quality (Prov. 31:22) and frequently associated with royalty and high officials (Judges 8: 26; Esther 1: 6, 8-15, Ezek 23: 6).

Red/Scarlet: Red represents the sacrificial blood of Christ and blood of Martyrs (2 kgs 3: 22-23, Rev 6: 4). Sin is also symbolized by red colour (Is 1: 18). In Revelation red is the colour of Satan, the great dragon ( $\operatorname{Rev} 12: 3$ ). It suggests power and murderous nature. "Babylon the great, the mother of whores and the earth's abomination", rides upon a scarlet coloured beast (Rev 17: 3-5).

Silver: In biblical language, refined silver symbolizes the purification of the soul (Ps. 66: 10) and the pure proven promises of God (Ps. 12: 6).

White: This usually represents purity (Ps. 51: 7, Isaiah. 1: 18, Dan 12:10) and holiness. In scripture, white garment frequently suggests this. On the Day of Atonement, the High Priest (Aaron) is instructed to put on the holy linen tunic (Lev. 6: 4, 32). God sits on a white throne and white cloth (Dan 7: 9, Rev. 20: 11) as is Christ at his transfiguration (Matt 28: 2-3); the "over comer" and the twenty-four elders (Revelation 3: 4-18, 4: 4; 7-9, 14; 19: 8) and the seven Angels (Rev 15: 6).

Krier (1988: p. 11) makes a list of sensuous elements that within a liturgy context in the Catholic Church will lend themselves to being experienced as symbols of Christ among the faithful (Table 2). 
Table 2. Other symbols showing the presence of Christ in the church.

\begin{tabular}{cccc}
\hline Fire & Water & Rock & Air \\
\hline Candles & Bowl of water & Stones & Sound of wind \\
Light & Pitcher & Pebbles & Clouds \\
Fire & Sprinkling & Rocks & Fan \\
Smoke & Water sounds & Boulders & Incense, smoke \\
Spotlight & Desert scene & Soil, Seed & Objects moving in air \\
Darkness & Dripping & Plants & Currents/Tides \\
\hline
\end{tabular}

The negative symbol is able to speak to a positive symbol. The absence or void of one may evoke longings for the presence of what is missing. For instance, darkness may bring a need for light, and dryness of desert for a desire for water.

\section{Adornment}

Decorative elements such as flowers, icons, images, pictures etc. help in no small manner to strengthen the faith. Many artists for centuries are inspired by the lives of Christ, the Virgin Mary, and the Saints. Such art has inspired men and women to be more faithful to the teachings of Christ and to be more reflective and live the teachings of Jesus, taught through religious paintings made by talented artists. The effect is more, when you have a firsthand experience through pilgrimage and contemplate the original images, you can find meaning behind every masterpiece. One learns more at times through pictures/images.

\subsection{Flowers}

Flowers are decorative elements that serve to beautify and are expression of love and thanksgiving to God the giver of all creation. One gives back to God the gift of nature and human hands. Added to this are Altar clothes which help to beautify the Altar and again are according to the mood of the celebration. The altar clothes tell the faithful whether it is a feast or not, that is celebrated.

\subsection{Icons and Images}

Icons and Images help to transcend the mind and heart to the sacred. The Cross of Christ is a constant reminder of Christ's love, suffering and self-giving for humanity. The image of the Blessed Virgin Mary for example; the Annunciation will make one contemplate the purity, holiness, simplicity, obedience etcetera and motherly role of Mary and salvific history. The image of Christ and the little children will portray the simplicity of the child and Christ's injunction-let the little children come to me for such belong the kingdom of heaven. The Stations of the Cross will immediately make one recall the way of the Cross, suffering and death of Christ on Calvary. One adopts a more penitential disposition. Images of the Saints and martyrs are symbols of persons who shed their blood for the sake 
of Christ for the reward of eternal life. These strengthen the believers daily and in the face of difficulties. The beautiful picture of the Last Supper is a symbol of the Holy Thursday meal of Christ and His Twelve Apostles, showing the confusion in the face of the bewildered Apostles as Christ reveals to them the betrayal by one of them. Da Vinci arranges them into four groups of three with Christ in the center and depicts the reaction of each disciple to the news. Christ remained calm, stable, undaunted and focused to accomplish His Father's will despite their confusion in contrast to the astonished expressions of the Apostles. Dwight (March, 23 2018) in his blog on "what's the use of Catholic Art" asserted that art in the Catholic Church is not just for hanging or like decorative items placed in the homes. Instead, he said that "art connects with faith. Each icon, statue, stained glass window or painting opens up new vista on our faith".

\subsection{Sacred Vestments: Vestures}

Dress used for religious ceremonies and rituals is referred to as ecclesiastical dress; in the Catholic Church each dress or vestment used has its meaning.

1) Alb: The Alb is a white gown made of white linen or cotton blend, donned by all Clerics. It is reserved for all those at the Altar. It is a full gown made to cover the cassock and worn over it. The Alb got its name from the Medieval Latin Alba (white). It represents the purity of the clerical state. Noonan Jr., James-Charles (1996: p. 338) says, "for one to don the Alb would be a symbol of a clerics baptismal state".

2) Chasuble: This is a simple garb worn over the alb. It is in colours depending on the mood of the celebration.

3) Amice: Amice comes from the Latin verb amicire meaning "to cover". The amice is the rectangular piece of white linen with two linen or cotton strings at the upper corners by which the Priest fastens it to the shoulders (over the cassock or clerical shirt) and under his arms and waist. A cross is sewn into the amice.

4) Stole: The word stole is Greek word derived from early Greek word for towel, stolas. All Clerics are entitled to the stole. It is required when vested or performing the sacramental role of their office. The stole connotes the sacramental role of the clerics and also in various colours as a complement to the chasuble.

5) Cope: This is a long and richly ornamented garb. The celebrant wears it at Vespers and during the Benediction of Blessed Sacrament.

\subsection{Symbols as Power, Having and Value}

Finally every symbol system has to do with Power, with having, and with value.

According to Power (1984: p. 207)

In the world of liturgy, things and words are not used as instruments, but celebrated and contemplated. Things and actions are not used as instruments to produce something, but the revelation they bear is received only in contemplation, in a reverence, for how they draw together "earth, sky, gods and mortals". 
Words are not functional and scientific but poetic. Language is always at its breaking point, and on this condition, being is revealed in it. Language recognizes its limits and seeks new interplay of meanings and images in the hope of new perspective and wonder.

Liturgical symbols when celebrated with its fullness of language calls participants to move away from questions, which bother on issues of faith and preoccupation ... to find in it a promise of the future (Power, 1984: p. 186).

\section{1) Power as symbol}

The liturgy's symbol of power as presented in the Gospel is associated with Christ being the one sent by God, because in him are all the tenderness, compassion and love of God, who first loves us. As gift from God, Christ empowers, heals and reconciles one with God and one with each other when received in faith. Faith is trust and belief in a higher power; God. Religion sets up for a person values, beliefs and morals and guides people through life. It also empowers the individual. This can influence social issues, family structures, education and politics. According to Pargament, KI (1997: p. 32) "Religion can be defined as a search for meaning in ways related to the Sacred". Religion can be seen as a personal relationship between one and God, as well as His Son Jesus and the Holy Spirit (Trinity). One believes without seeing and understanding fully. Dobson (2002: p. 19) noted that the Eucharistic symbolizes power, bringing wholeness and reconciling one with oneself and with another. "This power dwells with Christ and in his self emptying". Therefore the Eucharist is transforming. The church's liturgical readings are picked covering various issues and seasons and these touch the lives of the people. In liturgy the church remembers all who are dominated, all of natures' loveliness that is suppressed, all who resist, and all who testify. This is what touches God's presence and power in the world. In the prayer of the faithful, the various needs of the people are prayed for. The prayers of the faithful and belief in God give people hope, confidence and sense of purpose and support that things will be better in difficult times.

\section{2) Having}

The Gospel and the liturgy's symbol of having is poverty. Poverty or having is the economy of means, the simplicity of a table, the purity of the water that flows, touch of hands freely given and possessing nothing other than their touch. Poverty is the first sense of possessing nothing, yet having all. Poverty is Christ, the one remembered, who dies that all might become rich. At Mass, everyone is the same, poor and rich, everyone empties self to be filled by Christ, who died that all may be enriched.

\section{3) Value}

At Mass Christ offers himself to God as the Passover Sacrifice, and the faithful offer themselves along with him. According to Lovasik (1986: p. 12) his death becomes present, offered as our sacrifice to God in an unbloody and sacramental manner. The church values the members as a gift from God. Liturgy's word for value is the overflowing grace of God (Power, 1984: p. 210). This is also shown 
in the respect Christians have for each other, and their self esteem which is exemplified in their value for their faith, the supremacy and communion with God.

\section{Conclusion and Significance of the Study}

Everything from the beginning of the entrance into the Catholic Church, to its liturgical celebration is full of expressions and meaning that go beyond words to the very fabric of the heart. They are symbolic arts that speak with the aim of uplifting the mind to the spiritual. One needs to go beyond a mere visual appreciation to a deeper knowledge to be able to see the deeper meaning these symbols portray. Sacred art is therefore beautiful and true when it draws the individual to the contemplation of the mystery of God, the Creator, Saviour and Sanctifier. Sacred art is beautiful and true when it also evokes in one the genuine love for the giver of all things, and draws one into adoration and prayer therefore transforming one to live a better life.

Individual Catholic Faithful will be able to appreciate and draw spiritual benefit from reflecting on the various symbols in the Catholic Church. It can also help to lift the mind and heart of the individual to eternal (spiritual) realities through reflection. It can bring inner peace and appreciation of the goodness of God in creation/nature knowing that God created all things and saw that they were good. It will help man appreciate the ingenuity/creativity of man through arts and in recreating the world rather than wars. A man's mental health is improved upon when one is at peace with God, others and nature. A lot of health related issues: psychological, emotional and spiritual, can be taken care of when one is in touch with the inner self through meditation. Inner peace can be enhanced by a peaceful and serene environment as it could be found in reflecting on the Symbolic Arts in the Catholic Church. Christians also learn the truth about their faith from symbolic arts. They serve as moral lessons and are helpful also for the teaching of children. Symbolism and art give new ways of seeing and of being. Through appreciation of symbolic art, individuals or respected authorities can preserve edifices, as artefact of history and this can become tourist attractions and preservation of the earth.

\section{Conflicts of Interest}

The author declares no conflicts of interest regarding the publication of this paper.

\section{References}

Alva, W. S. (2002). Symbols of the Christian Faith. Grand Rapids, MI: William B. Eerdmans Publishing Company.

Bosch, P. F. (2001). Worship Workbench: Lift Up Your Hearts (Signs of Worship). http://www.worship.ca/as

Byrne, P. (1998). Liturgy in Worship. Minnesota: The Order of St Benedict Inc. Liturgical Press. 
Dewis, J. P. (2002). The Weekday Missal. London: Collins Liturgical Publications, William Collins Sons \& Co Ltd.

Dobson, T. E. (2002). How the Eucharist Can Transform Your Life (4th ed.). Mahwah, NJ: Paulist Press.

Dwight, L. (2018). What's the Use of Catholic Art? https://www.ncregister.com/blog/longenecker

Goldstein, B. E. (2008). Cognitive Psychology: Connecting Mind, Research, and Everyday Experience (2nd ed.). Belmont, CA: Thomson Wadsworth Publishing Company.

Krier, C. H. (1988). Symbols for All Seasons: Environmental Planning for Cycles A, B and C. San Jose, CA: Resource Publication, Inc.

Langer, S. K. (1980). Philosophy in a New Key: Symbolism of Reason, Rite and Art (3rd ed.). Cambridge, MA: Harvard University Press.

Le Joly, E. (1995). Remain in My Love: Meditations on the Gospel of St John. Bombay: St Paul's Press.

Lovasik (1986). The Holy Eucharist. New York: Catholic Boom Publishing Co. Macmillan Publishers.

Noonan Jr., J. C. (1996). The Church Visible: The Ceremonial Life and Protocol of the Roman Catholic Church. New York: Amaranth.

Pargament, K. I. (1997). The Psychology of Religion and Coping: Theory, Research, Practice. New York: Guilford Press.

Power, D. N. (1984). Unsearchable Riches the Symbolic Nature of Liturgy. Collegeville, MN: Pueblo Publishing Company, Inc. The Order of St Benedict, Inc.

Power, D. N. (1990). Worship, Culture and Theology. Washington DC: The Pastoral Press.

The Catechism of the Catholic Church (CCC) (2008). St. Pauls Pauline Publications Africa.

The Divine Office (2011). Catechesis by St. John Chrysostom: The Power of the Blood of Christ. 392, Cat 3: 13-19 Sc 50, 174-177. Nairobi: Kenya Pauline Publications Africa.

The New Jerusalem Bible (1990). Pocket Edition. London: Darton, Longman \& Todd Ltd.

Zimmerman, J. A. (1998). Liturgy and Music: Lifetime Learning. Collegeville, MN: The Order of St Benedict Inc. Liturgical Press. 